\title{
Polypropylene Fabric Ground Cover Effects on Weed Control and Profit in Elephant Foot Yam Cultivation
}

\author{
Maniyam Nedunchezhiyan ${ }^{1 *}$, Biswanath Sahoo $^{2}$, Kalidas Pati $^{3}$, \\ Vijay Bahadur Singh Chauhan ${ }^{3}$,Venkatraman Bansode ${ }^{3}$, J. Suresh Kumar ${ }^{3}$, Suchismita \\ Tripathy $^{4}$, Kishore Sahoo ${ }^{5}$, Kumari Sunita ${ }^{6}$, Madhuri Toppo $^{7}$ and Rituparna Munshi ${ }^{8}$ \\ ${ }^{1}$ Regional Centre of Indian Council of Agricultural Research-Central Tuber Crops Research \\ Institute, Bhubaneswar-751019, Odisha, India \\ ${ }^{2}$ Krishi Vigyan Kendra (OUAT), Badrak-756111, Odisha, India \\ ${ }^{3}$ Indian Council of Agricultural Research-Central Tuber Crops Research Institute, \\ Thiruvananthapuram-695017, Kerala, India \\ ${ }^{4}$ Dept. of Agronomy, OUAT, Bhubaneswar-751003 \\ ${ }^{5}$ Agronomist, OFR, RRTTS, Keonjhar-758002 \\ ${ }^{6}$ Krishi Vigyan Kendra, Madhopur, West Champaran-845454 \\ ${ }^{7}$ Krishi Vigyan Kendra, Jharsuguda - 768212, Odisha \\ ${ }^{8}$ Department of Horticulture, Institute of Agricultural Science, Ballygunge- 700019, India
}

*Corresponding author

\section{A B S T R A C T}

\begin{tabular}{l} 
K e y w o r d s \\
$\begin{array}{l}\text { Corm yield, Gross } \\
\text { income, Soil } \\
\text { microbes, Weed } \\
\text { biomass, Weed } \\
\text { control efficiency }\end{array}$ \\
\hline Article Info \\
$\begin{array}{l}\text { Accepted: } \\
\text { 11 June } 2020 \\
\text { Available Online: } \\
\text { 10 July } 2020\end{array}$ \\
\hline
\end{tabular}

Elephant foot yam [Amorphophallus paeoniifolius (Dennst.) Nicolson] competes with weeds throughout its growing period owing to its canopy orientation and wider spacing. Manual weeding is the most popular weed control method adopted in elephant foot yam irrespective of drudgery and labourious. A field experiment was conducted for two consecutive years (2016 and 2017) at the Regional Centre of Indian Council of Agricultural Research-Central Tuber Crops Research Institute, Bhubaneswar, Odisha, India to study the effects of polypropylene fabric ground cover (PFGC) on weed control in elephant foot yam. The treatment PFGC resulted in greater corm yield $\left(34.2\right.$ tha $\left.^{-1}\right)$ which was $253 \%$ higher over the weedy check, and 2.4 and $7.2 \%$ higher over 4 manual weedings at 30,60, 90 and 120 days after planting (DAP) $\left(33.4\right.$ tha $\left.^{-1}\right)$ and 2 manual weedings at 30 and 60 DAP along with post-emergence application of glyphosate at 90 DAP (31.9 tha $\left.{ }^{-1}\right)$, respectively. The treatment PFGC resulted in greater gross income (Rs $513000 \mathrm{ha}^{-1}$ ) and profit (Rs287500 ha ${ }^{-1}$ ) compared to other treatments. Use of PFGC resulted in greater populations of fungi, bacteria and actinomycetes, and enzymes of dehydrogenase, fluorescein diacetate, acid and alkaline phosphatase activities in post harvest soil than initial value that indicated the treatment PFGC could be a good weed control option in elephant foot yam. 


\section{Introduction}

Elephant foot yam [Amorphophallus paeoniifolius (Dennst.) Nicolson] is a starchy tuber crop grown in tropical, and subtropical regions, particularly in south-east Asia. Its modified under ground stem 'corm' is consumed as vegetable by preparing various delicious cuisines. The corms are alsoreported to have medicinal properties (Misra et al., 2002; Dey et al., 2010). The corms are rich in minerals and vitamins (Nedunchezhiyan et al., 2017a), and contain glucose, galactose and rhamnose, flavonoids, phenols, coumarins, terpenoids, sterols, tannins, steroids and alkaloids (Nataraj et al., 2009; Yadu and Ajoy, 2010). Khan et al., (2008) isolated amblyone (a triterpenoid) and 3, 5diacetylambulin (aflavonoid) from corms.

Weeds are potentially a major constraint on crop production and reduce yields significantly if not controlled. Weeds are major pests in humid and sub-humid tropics where adequate rainfall, temperature, and humidity favour their growth (Melifonwu, 1994) and are responsible for reducing quantity and quality of agricultural products by competing with natural and applied resources (Rao et al., 2015). If harvest is delayed, weed roots enter in to the corms of elephant foot yam and reduces the quality and makes unfit for consumption (Nedunchezhiyan and Misra, 2008). In elephant foot yam, crop-weed competition exists throughout crop growth period because of little coverage by the leaf canopy. Elephant foot yam plant produces erect single pseudo stem with umbrella shaped tripartite leaf canopy. Hence, it is planted at wider spacing to prevent overlapping of canopy from neighbouring plants. Further, elephant foot yam is propagated through corm setts, which takes long time (20-30 days) to sprout. Weeds often germinate and grow earlier than the elephant foot yam and smother the crop.
Weed infestation at early stage of the crop development causes severe yield reduction; up to $100 \%$ in wide spaced plantings (Nedunchezhiyan et al., 2018). Weeds in elephant foot yam compete below ground for water and nutrients, and above ground for light and space, and inhibit growth and development of the crop. Weeding alone requires 150-200 man daysha ${ }^{-1}$ i.e.more than $30 \%$ of total labour (Ravindran et al., 2010; Nedunchezhiyan et al., 2013). Manual weeding is expensive, tedious and time consuming. However, application of herbicides for weed control at pre- or postemergence can reduce dependency on manual weeding and reduce cost per weeding. But, herbicides applied to control weeds in the crop field have direct, or indirect, consequences on non-targeted organisms including soil microflora which are responsible for numerous biological processes essential for crop production (Riaz et al., 2007; Latha and Gopal, 2010). It has been reported that some microorganisms are able to degrade herbicides, while others are adversely affected depending on type of herbicide used (Sebiomo et al., 2011). Herbicides either stimulate, or depress, microbial growth depending on the type of chemicals, microbial species and environmental conditions (Zain et al., 2013).

Mulching with organic materials suppresses weed growth and improves soil microbial population (Jung et al., 2004; Chauhan et al., 2012; Das et al., 2012). However, availability of organic materials for mulching is a major constraint. Hence, polythene mulching is recommended in place of organic mulching for weed control in elephant foot yam (Sekhar et al., 2017). However, the major problem in polythene mulching is, it does not allow infiltration of water in to the soil. Thus, the crops grown under rainfed conditions suffer moisture stress. Now, polypropylene woven fabrics are available for mulching the crop 
plants which will overcome the problems of water infiltration in to the soil. One year study during 2015 on polypropylene woven fabric mulching in elephant foot yam revealed positive effects on crop yield and soil health (Nedunchezhiyan et al., 2018). Hence, present investigation was undertaken to study the effects of polypropylene fabric on weed control and profit in elephant foot yam cultivation.

\section{Materials and Methods}

A field experiment was conducted at the Regional Centre of Indian Council of Agricultural Research-Central Tuber Crops Research Institute (20 $14^{\circ} 50^{\prime \prime} \mathrm{N}$ and $85^{\circ} 47^{\prime}$ 06" E), Bhubaneswar, Odisha, India during 2016 and 2017.The climate of the experimental site was warm and humid in summer and cool and dry in winter. The experiment was conducted in sandy clay loam soil with pH 6.67 (Table 1). The soil was low in organic carbon $(0.36 \%)$ with available $\mathrm{N}, \mathrm{P}$ and $\mathrm{K}$ content was $172.4,25.1$ and $178.2 \mathrm{~kg}$ $\mathrm{ha}^{-1}$, respectively (Table 1 ). The experiment was laid out in a randomized block design (RBD) with three replications. The treatments consisted of combinations of herbicides, manual weeding and polypropylene fabrics ground cover (PFGC): $\mathrm{T}_{1}$ - Pendimethalin @ $1000 \mathrm{~g} \mathrm{ha}^{-1}[1$ day after planting (DAP)]+Glyphosate @ $2000 \mathrm{~g} \mathrm{ha}^{-1}$ (at 90 DAP); $\mathrm{T}_{2}$ - Metribuzin @ $525 \mathrm{~g} \mathrm{ha}^{-1}$ (at 1 DAP)+Glyphosate @ $2000 \mathrm{~g} \mathrm{ha}^{-1}$ (at 90 DAP), $\mathrm{T}_{3}$ - Pendimethalin @ $1000 \mathrm{~g} \mathrm{ha}^{-1}$ (at 1 DAP)+tank mix of Pyrithiobac sodium @ $62.5 \mathrm{~g} \mathrm{ha}^{-1}$ and Propiquizafop @ $62.5 \mathrm{~g} \mathrm{ha}^{-1}$ (at 90 DAP), $\mathrm{T}_{4}$-Metribuzin @ $525 \mathrm{~g} \mathrm{ha}^{-1}$ (at 1 DAP)+tank mix of Pyrithiobac sodium @ $62.5 \mathrm{~g} \mathrm{ha}^{-1}$ and Propiquizafop @ $62.5 \mathrm{~g} \mathrm{ha}^{-1}$ (at 90 DAP), $\mathrm{T}_{5}$-Pendimethalin @ $1000 \mathrm{~g} \mathrm{ha}^{-1}$ (at 1 DAP)+2 manual weedings (at 60 and 90 DAP), $\mathrm{T}_{6}$ - Metribuzin @ $525 \mathrm{~g} \mathrm{ha}^{-1}$ (at 1 DAP)+2 manual weedings (at 60 and 90 DAP), $T_{7}-2$ manual weedings (at 30 and 60
DAP)+Glyphosate @ $2000 \mathrm{~g} \mathrm{ha}^{-1}$ (at 90 DAP), $\mathrm{T}_{8} \quad-2$ manual weedings (at 30 and 60 DAP)+tank mix Pyrithiobac sodium @ $62.5 \mathrm{~g}$ $\mathrm{ha}^{-1}$ and Propiquizafop @ $62.5 \mathrm{~g} \mathrm{ha}^{-1}$ (at 90 DAP), $\mathrm{T}_{9}-\mathrm{PFGC}, \mathrm{T}_{10}-4$ manual weedings (at 30, 60, 90 and 120 DAP), and $\mathrm{T}_{11}$-Control (weedy check). Farmyard manure @ 10 t ha ${ }^{1}$ was uniformly incorporated before levelling in all the treatments and ridges were formed at the spacing of $90 \mathrm{~cm}$.

Healthy whole corm of variety Gajendra, weighing approximately $400 \mathrm{~g}$, treated with cow dung slurry (10 kg of fresh cow dung dissolved in $10 \mathrm{~L}$ of water and mixed with 50 g Trichoderma) one day before were planted at a $90 \times 90 \mathrm{~cm}$ spacing on ridges. The preemergence herbicides (pendimethalin and metribuzin) were applied one day after planting corms. The post-emergence herbicides (glyphosate, and a tank mix of pyrithiobac sodium and propiquizafop) were applied directly on weeds at 90 DAP. Using a spray volume of $500 \mathrm{~L} \mathrm{ha}^{-1}$ of water, herbicides were applied without drift on elephant foot yam plants with a manually operated knapsack sprayer with a flat-fan nozzle attached to a hood. The PFGC is a polypropylene woven fabric $\left(100 \mathrm{gm}^{-2}\right)$ which allows air and water to pass through to the soil, but suppresses weed emergence and growth. The PFGC was spread on the ridge and furrows and the ends covered with soil. Holes were made, and corms were planted using a $10 \mathrm{~cm}$ diameter pipe. The recommended dose of water soluble fertilizers @ 120-60-120 kg ha ${ }^{-1}$ of $\mathrm{N}-\mathrm{P}_{2} \mathrm{O}_{5}-\mathrm{K}_{2} \mathrm{O}$ was applied through drip fertigation. The crop was planted $1^{\text {st }}$ May and harvested $31^{\text {st }}$ December in both the years.

Soil samples taken before and two years after experimentation were preserved in at $4^{\circ} \mathrm{C}$ in a refrigerator and used for estimation of microbial variables. Nutrient Agar, Potato Dextrose Agar and Starch Casein Agar media 
were used for isolation of bacteria, fungi and actinomycetes, respectively. After serial dilution, $1.0 \mathrm{~mL}$ of required dilution $\left(10^{-4}\right.$ for fungi and actinomycetes and $10^{-5}$ for bacteria) was inoculated in to respective Petri plates. The soil sample was spread over the media via a flame sterilized bent glass rod and all plates incubated in the dark at $37^{\circ} \mathrm{C}$. After microbial colonies were readily visible (2-7 days for bacteria and fungi and 7-14 days for actinomycetes), numbers of colonies on each plate were counted. The number of cfu g ${ }^{-1}$ dry soil was estimated by taking the soil dilution factor and soil moisture content into account. Dehydrogenase activity (DHA) and fluorescein diacetate hydrolysis assay (FDA) in soils was determined by the method described by Casida (1977) and Green et al., (2006), respectively. Acid phosphormonoesterase (AcP) and alkaline phosphomonoesterase (AlP) activities were determined by following the procedure of Tabatabai and Bremner (1969).

Using quadrant $(50 \times 50 \mathrm{~cm})$ weeds were removed from two locations before each manual weeding and post emergence herbicide application in the respective treatments and at harvest from all treatments. Weeds were separated by species, initially sun-dried and placed in a forced air oven at $70^{\circ} \mathrm{C}$ to dry until constant weight was attained. Weed control efficiency (WCE) was calculated by the following formula and expressed in percentage:

$$
\mathrm{WCE}=\frac{\begin{array}{c}
\text { Weed biomass } \\
\text { in control plot }- \text { treated plot }
\end{array}}{\text { Weed biomass in control plot }}
$$

The cost of cultivation was calculated by considering variable cost and interest rate and depreciation on capital cost of PFGC. The life period of PFGC is 5 years. The profit and benefit cost ratio were calculated as follows:
Profit $\left(\mathrm{Rs} \mathrm{ha}^{-1}\right)=$

Gross income ( $\left.\mathrm{Rs} \mathrm{ha}^{-1}\right)$-cost of cultivation (Rs $\mathrm{ha}^{-1}$ )

Benefit cost ratio $=\frac{\operatorname{Gross} \text { income }\left(\mathrm{Rs} \mathrm{ha}^{-1}\right)}{\text { Cost of cultivation }\left(\mathrm{Rs} \mathrm{ha}^{-1}\right)}$

The data on weeds were subjected to square root transformation before statistical analysis. The data collected were subjected to analysis of variance (ANOVA) for RBD using SAS (ver. 11.0, SAS Inc., Cary, NC). The homogeneity of error variance was tested using Bartlett's $\chi^{2}$-test. As the error variance was homogeneous, pooled analysis was done. Comparison of treatment means for significance at $P=0.05$ was done using least significant difference (LSD) (Gomez and Gomez, 1984).

\section{Results and Discussion}

\section{Weather and weed flora}

The weather parameters during the crop growing period of 2016 and 2017 were averaged. The average monthly maximum temperature was ranged $29.2-38.8^{\circ} \mathrm{C}$; the average monthly minimum temperature was ranged $14.8-26.9^{\circ} \mathrm{C}$. The average monthly relative humidity was ranged $63.9-85.2 \%$ during the crop growing period. The average annual rainfall received during the crop growing period was $1385.1 \mathrm{~mm}$. Plants were irrigated through a drip system during dry spells at $80 \%$ of cumulative pan evaporation and an average of $285 \mathrm{~mm}$ water per year was applied.

In the experimental field 21 numbers of weed species were observed during cropping period (Table 1). Among them 16 broad leaved weeds, four grasses and a sedge were noticed. 
The weed flora observed was specific to the location and climate of the experimental site. High rainfall and relative humidity during crop growing period resulted in emergence of more number of weed species. Kumar et al., (2019) reported 24 weed species in elephant foot yam field in Thiruvananthapuram, Kerala, India. Nandan et al., (2020) reported 33 weed species in the seed bank in Inceptisols of Patna, Bihar, India. Though multiple fleshes of weed species emerged from the seed bank, Celosia argentea L., Digitatia sanguinalis (L.) Scop. and Cleome viscosa L. were dominated the other weed flora throughout the crop growing period. However, in the shaded conditions at the later stage of crop growing period especially in treatment $\mathrm{T}_{10}$, Euphorbia hirta L., Oldenlandia corymbosa L. and Phyllanthus niruri L. were emerged in more numbers. Nandan et al., (2020) reported that the most dominant weed flora in the cropped field was depending on the ecosystem in which the crop was grown.

\section{Weed biomass and WCE}

Weed biomass production was influenced by weed control treatments (Table 2). Among all the treatments, $\mathrm{T}_{9}$ resulted in lower weed biomass production $\left(9.7 \mathrm{~g} \mathrm{~m}^{-2}\right)$ which was $95.9 \%$ lesser than $\mathrm{T}_{11}$. This was due to suppression of weed germination and emergence owing to complete cover of the ground by polypropylene fabrics. The next best treatment was $\mathrm{T}_{10}$ which resulted in $94.4 \%$ reduction in weed biomass production compared to $\mathrm{T}_{11}$ owing to removal of weeds by manually 4 times (at 30, 60, 90 and 120 DAP) in a cropping season. The treatments $\mathrm{T}_{1}, \mathrm{~T}_{2}, \mathrm{~T}_{3}$ and $\mathrm{T}_{4}$ resulted in relatively higher weed biomass production. In a long duration crop like elephant foot yam, pre- and postemergence herbicides combinations alone were not sufficient for adequate weed control. Sekhar et al., (2017) and Kumar et al., (2019) reported that herbicide application limit the weed growth but could not control the weeds appreciable level in elephant foot yam due to their short life in the soil. Greater WCE was achieved in treatments $\mathrm{T}_{9}(95.9 \%)$ and $\mathrm{T}_{10}(94.5 \%)$ compared to other treatments owing to lesser weed biomass production. The treatment $\mathrm{T}_{7}$ resulted in $85.4 \%$ WCE. In this treatment 2 manual weeding (30 and 60 DAP) followed by glyphosate application (90 DAP) reduced the weed pressure.

\section{Yield}

The treatment $\mathrm{T}_{9}$ resulted in greater corm yield (34.2 $\mathrm{t} \mathrm{ha} \mathrm{ha}^{-1}$ compared to other treatments (Table 2), which was $252.6 \%$ higher yield than $\mathrm{T}_{11}\left(9.7 \mathrm{t} \mathrm{ha}^{-1}\right)$. The higher corm yield in this treatment was due to lower weed biomass production and higher weed control efficiency (Table 2). Sekhar et al., (2017) reported that maximum corm yield was under black polythene mulching of elephant foot yam. Lamont (2005) reported that covering the soil with polythene increased the crop production efficiency and productivity by controlling weeds, improving soil conditions for plant growth through its influence on the root zone temperature, and providing better assimilates of nutrients by reducing the leaching of fertilizers. The treatments $\mathrm{T}_{10}$ and $\mathrm{T}_{7}$ resulted in $244.3 \%$ and $228.9 \%$ higher corm yield than $\mathrm{T}_{11}$ (Table 2). These treatments also indicated that keeping field weed free for longer periods may be improving growth and development of elephant foot yam. However the corm yield in $\mathrm{T}_{10}$ and $\mathrm{T}_{7}$ was lesser than $\mathrm{T}_{9}$ inspite of keeping field weed free conditions for considerable period of time. Under polythene mulched conditions, soil moisture and nutrients were conserved (Abu-Rayyen and Abu-Irmaileh, 2004) that resulted in 22.4$28.8 \%$ higher corm yield over exposed soil conditions (no mulch) in elephant foot yam (Goswami and Saha, 2006). Corm yield data 
presented in Table 2 also indicated that application of herbicides alone was not having significant impact because of lower WCE. Sekhar et al., (2017) and Kumar et al., (2019) also reported lesser efficacy of herbicides if applied alone in elephant foot yam. Among pre-emergence application of herbicides, pendimethalin was more effective than metribuzine and among post-emergence herbicides glyphosate was more effective than the tank mix of pyrithiobac sodium and propiquizafop. The treatment $\mathrm{T}_{11}$ (weedy check) resulted in lower corm yield owing to season long crop-weed competition, which was indicated by higher weed biomass production and lower WCE (Table 2).

\section{Economics}

Weed control methods influenced cost of cultivation, gross income, profit and benefit cost ratio (Table 1). Greater cost of cultivation was observed in treatment $T_{9}$ followed by treatment $T_{10}$. However, the cost difference between both the treatments was just Rs $1000 \mathrm{ha}^{-1}$. Though initial cost of PFGC was higher, considering its longevity the variable cost was nearly equal to 4 manual weeding cost. The treatment $\mathrm{T}_{9}$ resulted in maximum gross income (Rs 513000ha ${ }^{-1}$ ) and it was followed by treatment $\mathrm{T}_{10}$ $\left(\mathrm{Rs} 501000 \mathrm{ha}^{-1}\right)$. Greater gross income in these treatments was due to higher corm yield. The treatment $\mathrm{T}_{9}$ resulted in greater profit (Rs $287500 \mathrm{ha}^{-1}$ ) (Table 2). Higher profit was also realized in treatments $\mathrm{T}_{10}(\mathrm{Rs}$ $\left.276500 \mathrm{ha}^{-1}\right)$ and $\mathrm{T}_{7}\left(\mathrm{Rs} 272200 \mathrm{ha}^{-1}\right)$ due to higher corm yield in former case and lower cost of cultivation in latter case (Table 2). The treatment $\mathrm{T}_{9}$ recorded 4.0 and $5.6 \%$ higher profit than $T_{10}$ and $T_{7}$, respectively. The treatment $\mathrm{T}_{7}$ resulted in greater benefit cost ratio (2.32) owing to lower cost of cultivation and moderate corm yield. The treatments $\mathrm{T}_{9}$ (2.27) and $\mathrm{T}_{10}$ (2.23) also resulted in higher benefit cost ratio than other treatments except $\mathrm{T}_{7}$ owing to higher corm yield.

\section{Soil organic carbon}

Weed control methods affected soil organic carbon content (Table 3). The post-harvest soil organic carbon content increased in all treatments except $T_{10}$ compared to initial status (Table 3 ). The treatment $\mathrm{T}_{7}$ resulted in greater soil organic carbon. It was $33.3 \%$ higher over initial value after two years of experimentation. Application of post emergence herbicide glyphosate at 90 DAP resulted in drying and decomposition of weed biomass in situ that increased soil organic carbon content. The treatment $\mathrm{T}_{11}$ also resulted in higher soil organic carbon content. In this treatment continuous presence of weeds (the highest biomass production) (Table 2) added higher organic carbon in to the soil. Organic amendments, and associated plant residues, may supply additional sources of labile C in soil (Carpenter-Boggs et al., 2000). The treatment $T_{9}$ recorded moderately higher soil organic carbon than the treatment $\mathrm{T}_{10}$ and initial value. This might be accumulation of organic carbon in situ due to dead microbial populations, organic exudates from the roots of crop plants and decaying of germinating weed seeds as well as prevention of decomposition of soil organic matter. Increasing number of manual weeding decreased soil organic carbon content. The treatment $T_{10}$ resulted in lower soil organic carbon. This might be due to clean cultivation. Continuous disturbing and exposure of soil enhances oxidative processes and respiration, and increases emission of $\mathrm{CO}_{2}$ from the soil by faster decomposition of soil organic matter (Chatskikh and Olesen, 2007). The return of weed residue to the soil is negligible in this treatment. Elephant foot yam produces 3-4 leaves with petioles (pseudostem) per plant (Nedunchezhiyan et al., 2017a), which were intact with corm till harvest of the corm. Crop residues were not available before harvest. 


\section{Soil microbial populations}

Post harvest soil microbial population was higher than initial soil (Table 3). Availability of sufficient soil moisture, favourable relative humidity along with substrates, released by dead and living roots of crop and weeds responsible for multiplication of microbes in the soil during cropping season in all the treatments. Weed control methods significantly influenced the post harvest soil microbial population (Table 3 ). In this present experiment, the increase of microbial population in post emergence application of glyphosate after two years might be due to increase of organic carbon by slow decomposition of dead weeds in situ and release of essential nutrients from weeds which act as substrate for microbial multiplication. Immediately after herbicide application the microbial population may be decreased and 15-20 days after application, the herbicide decomposes, and microbial populations start multiplying (Nedunchezhiyan et al., 2017b).

The microbial multiplication can be due increased supply of nutrients available from weeds killed by herbicides, or to protocooperative influence of micro-organisms in the rhizosphere of (Lokose, 2017). Ghosh et al., (2012) found that for all cases of herbicidal treatments, total bacteria recovered from initial loss and exceeded initial counts. Bera and Ghosh (2013) reported that herbicide treatments initially resulted in decreased microbial counts but with the degradation of the herbicides within a considerable time, the population exceeded the initial count. In the present investigation, due to high rainfall the glyphosate might have been leached out or converted into harmless secondary metabolites in the soil. When glyphosate binds to soil, it becomes inactive, losing its antimicrobial properties and can be readily degraded by microorganisms to $\mathrm{CO}_{2}$ and provide a source of phosphorus, nitrogen and carbon for microorganisms (Nedunchezhiyan et al., 2017b). Haney et al., (2000, 2016) reported increased soil microbial biomass, respiration, and carbon and nitrogen mineralization after glyphosate application. Application of glyphosate in short duration crops like maize (Zea mays L.) and soybean [Glycine max (L.) Merr.] has decreased bacterial diversity at harvest (Barriuso et al., 2010), but in long duration elephant foot yam crop bacterial diversity may be recovered. The treatment $\mathrm{T}_{9}$ resulted in greater microbial populations than $\mathrm{T}_{10}$ and initial value. The microclimate developed under PFGC might be favoured for microbial growth and multiplication.

\section{Soil enzyme activities}

The treatment $\mathrm{T}_{7}$ resulted in maximum dehydrogenase, fluorescein diacetate, acid and alkaline phosphatase activities in the soil (Table 3). Higher soil enzyme activities in these treatments might be due to higher organic carbon content and microbial activity in the soil. Increased soil dehydrogenase, fluorescein diacetate and phosphatase activities might be ascribed to greater availability of substrates that support these activities (Kremer and Li, 2003).Soil phosphatase activity was closely related to soil organic matter content, supporting reports that elevated organic matter levels promote soil phosphatase activity (Frankenberger and Dick, 1983; Jordan et al., 1995). The treatment $\mathrm{T}_{9}$ resulted in higher enzyme activities than $\mathrm{T}_{10}$ and initial value. This might be due to higher soil organic carbon and microbial populations (Table 3). The lowest dehydrogenase, fluorescein diacetate, acid and alkaline phosphatase activities in the soils were noticed in $\mathrm{T}_{10}$. This might be ascribed to lower organic carbon content and microbial activity in the soil. 
Table.1 Weed flora in elephant foot yam field during crop growing period

\begin{tabular}{|c|c|}
\hline Scientific name & Common name \\
\hline \multicolumn{2}{|l|}{ Sedges } \\
\hline Cyperus rotundus $\mathrm{L}$. & Purple nutsedge \\
\hline \multicolumn{2}{|l|}{ Grasses } \\
\hline Dactyloctenium aegypticum (L.) Beauv. & Crowfoot grass \\
\hline Digitatia sanguinalis (L.) Scop. & Large crabgrass \\
\hline Cyanodon dactylon (L.) Pers. & Bermudagrass \\
\hline Echinochloa crusgalli Beauv. & Barnyard grass \\
\hline \multicolumn{2}{|l|}{ Broad leaved weeds } \\
\hline Ageratum conyzoides $\mathrm{L}$. & Billgoat weed \\
\hline Borreria hispida (L.) Schum. & Shaggy button weed \\
\hline Cassia occidentalis $\mathbf{L}$. & Coffee senna \\
\hline Celosia argentea $\mathrm{L}$. & White cockscomb \\
\hline Cleome viscosa $\mathrm{L}$. & Tick weed \\
\hline Commelina benghalensis $\mathrm{L}$. & Tropical spiderwort \\
\hline Convolvulus arvensis $\mathrm{L}$. & Field bind weed \\
\hline Corchorus olitorius L. & Jute mallow \\
\hline Euphorbia hirta L. & Asthma-plant \\
\hline Melilotus indicus L. & Sweet clover \\
\hline Mimosa pudica $\mathbf{L}$. & Touch-me-not \\
\hline Oldenlandia corymbosa $\mathbf{L}$. & Diamond flower \\
\hline Phyllanthus niruri $\mathrm{L}$. & Stonebreaker weed \\
\hline Portulaca oleracea L. & Purslane weed \\
\hline Trianthema portulacastrum $\mathrm{L}$. & Giant pigweed \\
\hline Tridax procumbens & Coatbuttons \\
\hline
\end{tabular}


Table.2 Effects of weed control method on weed biomass, weed control efficiency, yield and economics in elephant foot yam

\begin{tabular}{|c|c|c|c|c|c|c|c|}
\hline Treatment $^{\mathrm{z}}$ & $\begin{array}{c}\text { Weed } \\
\text { biomass } \\
\left(\mathrm{g} \mathrm{m}^{-2}\right)\end{array}$ & $\begin{array}{c}\text { Weed control } \\
\text { efficiency } \\
(\%)\end{array}$ & $\begin{array}{l}\text { Corm } \\
\text { yield } \\
\left(\mathbf{t} \mathbf{h a}^{-1}\right)\end{array}$ & $\begin{array}{c}\text { Cost of } \\
\text { cultivation } \\
\left(\operatorname{Rs~ha}^{-1}\right)\end{array}$ & $\begin{array}{c}\text { Gross } \\
\text { income } \\
\left(\mathbf{R s ~ h a}^{-1}\right)\end{array}$ & $\begin{array}{c}\text { Profit } \\
\left(\text { Rs ha }^{-1}\right)\end{array}$ & $\begin{array}{c}\text { Benefit } \\
\text { cost } \\
\text { ratio }\end{array}$ \\
\hline $\mathbf{T}_{1}$ & $\begin{array}{c}9.9 * * \\
(97.2)^{*}\end{array}$ & 58.7 & 20.8 & 183300 & 312500 & 129200 & 1.70 \\
\hline $\mathbf{T}_{2}$ & $\begin{array}{c}10.0 \\
(100.8)\end{array}$ & 57.2 & 20.3 & 182400 & 303400 & 121000 & 1.66 \\
\hline $\mathbf{T}_{\mathbf{3}}$ & $7.5(55.8)$ & 76.3 & 24.1 & 187400 & 360600 & 173200 & 1.92 \\
\hline $\mathbf{T}_{4}$ & $7.7(59.4)$ & 74.8 & 22.7 & 186700 & 339100 & 152400 & 1.82 \\
\hline $\mathbf{T}_{5}$ & $6.7(45.0)$ & 80.9 & 27.3 & 204000 & 408800 & 204800 & 2.00 \\
\hline $\mathbf{T}_{6}$ & $6.9(48.1)$ & 79.6 & 25.5 & 203000 & 382100 & 179100 & 1.88 \\
\hline $\mathbf{T}_{7}$ & $5.9(34.6)$ & 85.4 & 31.9 & 206400 & 478600 & 272200 & 2.32 \\
\hline $\mathbf{T}_{8}$ & $7.4(55.4)$ & 76.5 & 23.5 & 202100 & 352400 & 150300 & 1.74 \\
\hline $\mathbf{T}_{9}$ & $3.1(9.7)$ & 95.9 & 34.2 & 225500 & 513000 & 287500 & 2.27 \\
\hline $\mathbf{T}_{10}$ & $3.6(13.1)$ & 94.5 & 33.4 & 224500 & 501000 & 276500 & 2.23 \\
\hline $\mathbf{T}_{11}$ & $\begin{array}{c}15.3 \\
(235.3)\end{array}$ & - & 9.7 & 172800 & 145500 & $(-) 27300$ & 0.84 \\
\hline $\begin{array}{c}\text { LSD } \\
(P=0.05)\end{array}$ & 0.6 & - & 4.3 & 22000 & 65400 & 26400 & 0.24 \\
\hline
\end{tabular}

*The data in the parenthesis are original; $* * \sqrt{\text { transformed values }}$

Table.3 Effects of weed control method on organic carbon, microbial population and soil enzyme activities in elephant foot yam

\begin{tabular}{|c|c|c|c|c|c|c|c|c|}
\hline Treatment $^{\mathrm{z}}$ & $\begin{array}{c}\text { Organic } \\
\text { carbon }(\%)\end{array}$ & $\begin{array}{c}\text { Fungi } \\
\left.\times_{10} \mathrm{cfu}^{-1}\right)\end{array}$ & $\begin{array}{c}\text { Bacteria } \\
\left(\text { x10 }^{5} \mathrm{cfu} \mathrm{g}^{-1}\right)\end{array}$ & $\begin{array}{l}\text { Actinomycetes } \\
\left(\mathrm{x10}^{4} \mathrm{cfu}^{-1}\right)\end{array}$ & $\begin{array}{l}\text { s Dehydrogenase } \\
\left(\mu \mathrm{g} \text { TPF } \mathrm{hr}^{-1} \mathrm{~g}^{-1}\right)\end{array}$ & $\begin{array}{l}\text { Fluorescein } \\
\text { diacetate } \\
\left(\mu \mathrm{g} \mathrm{g}^{-1} \mathrm{hr}^{-1}\right)\end{array}$ & 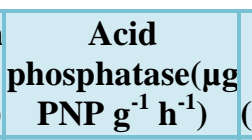 & $\begin{array}{c}\text { Alkaline } \\
\text { phosphatase } \\
\left(\mu \mathrm{g} \text { PNP g } \mathbf{g}^{-1} \mathrm{~h}^{-1}\right)\end{array}$ \\
\hline $\begin{array}{l}\text { Initial } \\
\text { value }\end{array}$ & 0.36 & 10 & 10 & 8 & 0.545 & 1.182 & 33.16 & 25.23 \\
\hline $\mathbf{T}_{1}$ & 0.42 & 27 & 30 & 27 & 0.789 & 1.324 & 51.31 & 33.74 \\
\hline $\mathbf{T}_{2}$ & 0.40 & 28 & 32 & 26 & 0.777 & 1.256 & 48.52 & 32.03 \\
\hline $\mathbf{T}_{3}$ & 0.42 & 26 & 26 & 25 & 0.756 & 1.206 & 47.92 & 32.05 \\
\hline $\mathbf{T}_{4}$ & 0.43 & 27 & 24 & 24 & 0.749 & 1.238 & 45.59 & 30.63 \\
\hline $\mathbf{T}_{5}$ & 0.37 & 28 & 27 & 25 & 0.732 & 1.318 & 42.28 & 30.39 \\
\hline$T_{6}$ & 0.38 & 25 & 26 & 25 & 0.856 & 1.226 & 40.95 & 28.63 \\
\hline $\mathbf{T}_{7}$ & 0.48 & 32 & 36 & 28 & 0.916 & 1.432 & 66.36 & 42.34 \\
\hline $\mathbf{T}_{8}$ & 0.42 & 28 & 28 & 25 & 0.842 & 1.328 & 53.72 & 34.60 \\
\hline $\mathbf{T}_{9}$ & 0.38 & 26 & 26 & 25 & 0.702 & 1.246 & 52.10 & 34.22 \\
\hline $\mathbf{T}_{10}$ & 0.32 & 21 & 24 & 20 & 0.556 & 1.126 & 37.55 & 26.12 \\
\hline $\mathrm{T}_{11}$ & 0.44 & 30 & 32 & 24 & 0.852 & 1.364 & 51.82 & 41.74 \\
\hline $\begin{array}{c}\text { LSD } \\
(P=0.05)\end{array}$ & 0.12 & 0.2 & 0.2 & 0.2 & 0.073 & 0.095 & 2.98 & 2.16 \\
\hline
\end{tabular}


In conclusion, the PFGC controlled the weeds efficiently and resulted in greater corm yield, income and profit in elephant foot yam. The PFGC also resulted in higher soil organic carbon, microbial population and soil enzyme activities than traditional and popular 4 manual weedings at 30, 60, 90 and 120 DAP. Hence, the PFGC could be a good weed control option in elephant foot yam. This study also revealed that in large farms where initial investment on PFGC was not possible and herbicide application was acceptable in that conditions, 2 manual weeding at 30 and 60 DAP+glyphosate (at 90 DAP) might be considered as an alternative method of weed control in elephant foot yam.

\section{Acknowledgements}

The authors are thankful to the Head, Regional Centre of ICAR-CTCRI, Bhubaneswar, Odisha, India for providing facilities for conducting the above investigation.

\section{References}

Abu-Rayyan, A.M. and Abu-Irmaileh,B.E. 2004. Onion development and yield in response to manual cultivation, herbicides or coloured mulches. J. Veg. Crop Prod. 10(1), 37-49.

Barriuso, J., Marín, S., Mellado, R.P., 2010. Effect of the herbicide glyphosate on glyphosate-tolerant maize rhizobacterial communities: a comparison with preemergency applied herbicide consisting of a combination of acetochlor and terbuthylazine. Environ. Microbio. 12, 1021-1030.

Bera, S., Ghosh, R.K., 2013. Soil microflora and weed management as influenced by atrazine 50\% WP in sugarcane. Univ. J. Agric. Res. 1(2), 41-47.

Carpenter-Boggs, L., Kennedy, A.D., Reganold,J.P., 2000. Organic and biodynamic management: effects on soil biology. Soil Sci. Soc. America J. 64, 1651-1659.

Casida Jr., L.E., 1977. Microbial metabolic activity in soil as measured by dehydrogenase determinations. App. Enviro. Microbio. 34, 630-636.

Chatskikh, D., Olesen, J.E., 2007. Soil tillage enhanced $\mathrm{CO}_{2}$ and $\mathrm{N}_{2} \mathrm{O}$ emission from loamy sand soil under spring barley. Soil Till. Res.97, 5-18.

Chatterjee, A., Pakrashi, S.C., 2001. The Treatise on Indian Medicinal Plants (reprinted edition). Publications and Information Directorate, New Delhi, India.

Chauhan, B.S., Singh, R.G., Mahajan, G., 2012. Ecology and management of weeds under conservation agriculture: A review. Crop Prot. 38, 57-65.

Das, T.K., Tuti, M.D., Sharma, R., Paul, T., Mirjha, P.R., 2012. Weed management research in India: An overview. Indian J. Agron. 57( $3^{\text {rd }}$ IAC Spl), 148-156.

Dey, Y.N., De, S., Ghosh, A.K., 2010. Antiinflammatory activity of methanolic extracts of Amorphophallus paeniifolius and its possible mechanism. Internat. $\mathbf{J}$. Phar. Biosci. 1(3), 1-8.

Frankenberger, W., Dick, W.A., 1983. Relationships between enzyme activities and microbial growth and activity indices in soils. Soil Sci. Soc. America J. 47, 945-951.

Ghosh, R.K., Jana, P., Nongmaithem, D., Pal, D., Bera, S., Mallick, S., Barman, S., Kole, R. K., 2012. Prospects of botanical herbicides in system of crop intensification in the Gangetic Inceptisols of India. Pro. 6th Internat. Workshop on Software Clones, 17-22 June 2012, Hangzhou, China.

Gomez, K.A., Gomez, A.A.S., 1984. Statistical Procedures for Agricultural Research. John Wiley Sons, New York. Goswami, S.B., Saha, S., 2006. Effect of 
organic and inorganic mulches on soilmoisture conservation, weed suppression and yield of elephant-foot yam (Amorphophallus paeoniifolius). Indian J. Agron., 51(2), 154-156.

Green, V.A., Stott, D.E., Diack, M.A., 2006. Assay for fluorescein diacetate hydrolytic activity: Optimization for soil samples. Soil Bio. Biochem. 38, 693-701.

Haney, R.L., Snseman, S.A., Hons,F.M., 2016. Roundup ultra on microbial activity and biomass from selected soils. J. Environ. Qual. 31, 730-735.

Haney, R.L., Snseman, S.A.,Hons, F.M., Zuberrer, D.A.M., 2000. Effect of glyphosate on soil microbial activity and biomass. Weed Sci. 48, 89-93.

Jordan, D., Kremer, R.J., Bergfield, W.A., Kim, K.Y., Cacnio, V.N. 1995. Evaluation of microbial methods as potential indicators of soil quality in historical agricultural fields. Bio. Fert. Soils 19, 297-302.

Jung, W.S., Kim, K.H., Ahn, J.K., Hahn, S.H., Chung, I.M., 2004. Allelopathic potential of rice (Oriza sativa L.) residues against Echinochloa crusgalli. Crop Prot. 23, 211-218.

Khan, A., Rahman, M., Islam,M.S., 2008. Antibacterial, antifungal and cytotoxic activities of amblyone isolated from Amorphophallus campanulatus Blume ex. Decne. Indian J. Pharm. 40(1), 4144.

Kremer, R.J., Li, J., 2003. Developing weedsuppressive soils through improved soil quality management. Soil Tillage Res. 72, 193-202.

Kumar,J.S., More, S.J., Byju, G., Sunitha,S., Veena, S.S., Nedunchezhiyan, M., Ravi, V., 2019. Effect of new generation herbicides on weed management, corm yield and economics of elephant foot yam [Amorphophallus paeoniifolius (Dennst.) Nicolson].Internat. J. Chem.
Stud. 7(3), 1213-1218.

Lamont, W.J., 2005. Plastics: modifying the microclimate for the production of vegetable crops. Hortic. Technol. 15, 477- 481.

Latha, P.C., Gopal, H., 2010. Effect of herbicides on soil microorganisms. Indian J. Weed Sci. 42(3\&4), 217-222.

Lokose, R.Y.P., 2017. Weed and nutrient management in maize (Zea mays L.) and cowpea (Vignaunguiculata L.) intercropping and residual effects on sesame (Sesamum indicum L.). Ph.D. Diss., Department of Agronomy, Orissa University of Agriculture and Technology, Bhubaneswar, Odisha, India.

Melifonwu, A.A., 1994. Weeds and their control in cassava. African Crop Sci. J. 2(4), 519-530.

Misra, R.S., Nedunchezhiyan, M., Swamy, T.M.S., Edison, S., 2002. Mass multiplication technique for producing quality planting material of Amorphophallus paeniifoilus. Tropical Sci. 34, 371-376.

Nandan, R., Singh, V., Kumar, V., Singh, S.S., Hazra, K.K., Nath, C.P., Malik, R.K., Poonia, S.P., 2020. Viable weed seed density and diversity in soil and crop productivity under conservation agriculture practices in rice-based cropping systems. Crop Prot. 136, https://doi.org/10.1016/j.cropro.2020.10 5210.

Nataraj, H.N., Murthy, R.L.N., Ramachandra, S., 2009. In vitro quantification of flavonoids and phenolic content of suran. Internat. J. Chem Tech Res. 1(4), 1063-1067.

Nedunchezhiyan, M., Ravindran, C.S., Ravi, V., 2013. Weed management in root and tuber crops in India: critical analysis. J. Root Crops 39(2), 13-20.

Nedunchezhiyan, M., Misra, R.S., 2008. Amorphophallus tubers invaded by 
Cynodon dactylon. Aroideana31, 129133.

Nedunchezhiyan, M., Byju, G., Ravi, V., George, J. 2017a. Spacio-temporal fertigation effects on growth, yield and nutrient use efficiency of elephant foot yam (Amorphophallus paeoniifolius). American-Eurasian J. Agric. Environ. Sci. 17(1), 63-77.

Nedunchezhiyan, M., Laxminarayana, K., Chauhan, V.B.S., 2018. Soil microbial activities and yield of elephant foot yam as influenced by weed management practices in Alfisols. Internat. J. Veg. Sci. 24(6), 583-596.

Nedunchezhiyan, M., Ravi, V., George,J., Veena, S.S.. 2017b. Effect of weed control methods on the yield and starch content of storage root of cassava (Manihot esculenta) and soil health. Indian J. Agric. Sci. 87(3), 342-349.

Rao, A.N., Wani, S.P., Ramesha, M., Ladha, J.K., 2015. Weeds and weed management of rice in Karnataka state, India. Weed Tech. 29(1), 1-17.

Ravindran, C.S., Ravi, V., Nedunchezhiyan, M., George, J., Naskar, S.K., 2010. Weed management in tropical tuber crops: An overview. J. Root Crops 36(2), 119-131.

Riaz, M., Jamil, M., Mahmood, T.Z., 2007.
Yield and yield components of maize as affected by various weed control methods under rainfed conditions of Pakistan. Internat. J. Agric. Bio. 9(1), 152-155.

Sebiomo, A., Ogundera, V.W., Bankole,S.A., 2011. Effects of four herbicides on microbial population, soil organic matter and dehydrogenase activity. African J. Biotech. 10(5), 770-778.

Sekhar, L., Thomas, C.G., Sindhu, P.V., 2017. Weed management in elephant foot yam [Amorphophallus paeoniifolius (Dennst.) Nicholson]. J. Trop. Agric. 55(1), 76-80.

Tabatabai, M.A., Bremner, J.M., 1969. Use of p-nitrophenyl phosphate for assay of soil phosphatase activity. Soil Bio. Biochem. 1, 301-307.

Yadu, N.D., Ajoy, K.G., 2010. Pharmacognistic evaluation and phytochemical analysis of the tuber of Amorphophallus paeniifolius. Internat. J. Pharm. Res. Dev. 2(9), 44-49.

Zain, N.M.M., Mohamad, R.B.,Sijam, K., Morshed, M.M., Awang, Y., 2013. Effects of selected herbicides on soil microbial populations in oil palm plantation of Malaysia: A microcosm experiment. African J. Microbio. Res. 7(5), 367-374.

\section{How to cite this article:}

Maniyam Nedunchezhiyan, Biswanath Sahoo, Kalidas Pati, Vijay Bahadur Singh Chauhan,Venkatraman Bansode, J. Suresh Kumar, Suchismita Tripathy, Kishore Sahoo, Kumari Sunita, Madhuri Toppo and Rituparna Munshi. 2020. Polypropylene Fabric Ground Cover Effects on Weed Control and Profit in Elephant Foot Yam Cultivation. Int.J.Curr.Microbiol.App.Sci. 9(07): 1100-1111. doi: https://doi.org/10.20546/ijcmas.2020.907.129 